\title{
Instrukcja z wychodka zlewni mleka: nikiforma - wymowa pokazowa - gatunek
}

Krzysztof Obremski

TEKSTY DRUGIE 2019, NR 3, S. 95-114

DOI: $10.18318 /$ td.2019.3.6 | ORCID: 0000-0001-6164-9207

Prozazaartystyczna... Narodzinyikarieraliteraturyfaktu są jedną z wielu reakcji właśnie na nieznośną literackość literatury.

Edward Redliński'

$\mathrm{O}$ biekt znaleziony w panoptykonie. Książki skarg i wniosków jako ready-made - to tytuł jednego z rozdziałów książki Grzegorza Grochowskiego Pamięć gatunków. Ponowoczesne dylematy atrybucji gatunkowej (Warszawa 2018). Tamże w przypisie została przywołana tytułowa instrukcja², która z pewnością mogłaby znaleźć się w Nikiformach Edwarda Redlińskiego - tryb warunkowy jest uzasadniony jedynie tym, że została odkryta przez Krzysztofa Lewandowskiego (ówcześnie pracownika

1 E. Redliński Kawa na ławę, w: Nikiformy, Czytelnik, Warszawa 1982, S. 5 .

2

G. Grochowski Pamięć gatunków. Ponowoczesne dylematy atrybucji gatunkowej, Stowarzyszenie Pro Cultura Litteraria, Wydawnictwo IBL PAN, Warszawa 2018, s. 193, przyp. 30.
Krzysztof Obremski

- prof. dr hab., Zakład Literatury Staropolskiej (Instytut Literatury Polskiej UMK).

Główne zainteresowania badawcze: nurt religijny literatury staropolskiej, sarmatyzm, teoria i praktyka retoryczna (szczególnie panegiryk i panegiryzm), współczesna humanistyka w interpretacji literatury staropolskiej. Redaktor książki Marcin Luter 1517-2017 (Wydawnictwo Naukowe UMK). Mieszka wToruniu. Kontakt: obremski@ umk.pl P 
brodnickiej spółdzielni mleczarskiej) już w połowie lat 8o., a więc nieco później, niż ukazała się owa antologia „tekstów gotowych”. To właśnie ostatnio wydana książka Pamięć gatunków stanowi usprawiedliwienie tego, że po raz trzeci mierzę się z wyzwaniem stanowionym instrukcją ${ }^{4}$.

\section{Społeczno-polityczny kontekst wychodkowej instrukcji}

W 1978 roku przyszło mi spełnić tzw. patriotyczny obowiązek służby wojskowej: wpierw Elbląg i Szkoła Oficerów Rezerwy, następnie Czarne i pułk czołgów. Rozpoznany w kurniku mechanizm społeczny, przez psychologów i socjologów zwany „porządkiem dziobania”, zaobserwowałem już w trakcie ćwiczeń musztry na placu elbląskich koszar ${ }^{5}$. Podczas inspekcji w pułku czołgów nocny alarm dowiódł bojowej gotowości - zaledwie, wyrwani ze snu żołnierze wbiegli do hangarów, wozy bojowe natychmiast wyjechały poza bramę jednostki (tyle że jedni żołnierze niczym sprinterzy dobiegli do

3 "Nikiformy Edwarda Redlińskiego to utwór literacki złożony z wielu odrębnych autentycznych tekstów użytkowych, które autor we wstępie określił jako „surowe kawałki rzeczywistości, surowe kawałki świadomości Polaków lat siedemdziesiątych". Wśród nich znalazły się m.in. oficjalne pisma obywateli kierowane do urzędów, komisji, prezydiów i związków, szablony napisów nagrobnych z kajetu kamieniarza, jadłospis baru mlecznego w Wasilkowie, więzienne grypsy i wiersze, księga skarg i wniosków z szafy WSS „Społem”, rozpisany na listy i zaświadczenia z izby wytrzeźwień dramat dysfunkcyjnej rodziny czy erotyczny dziennik księgowej pełen skrupulatnej buchalterii". M. Bukowiecka Antyliterackie, a więc literackie. O "Nikiformach" Edwarda Redlińskiego, "Teksty Drugie” 2015 nr 4, s. 326.

4 Por. dwie wcześniejsze publikacje poświęcone tytułowej instrukcji: K. Obremski „Retoryka” w wychodku zlewni mleka, "Teksty Drugie" 2005 nr 5, s. 213-218; K. Obremski Instrukcja w wychodku zlewni mleka: władza - głupota - retoryka - komizm, w: tegoż Ciało - płeć - kultura, Wydawnictwo Naukowe UMK, Toruń 2015, s. 65-86. Niejako siłą rzeczy pewne powtórzenia będą nieuniknione - jednak zawsze intencjonalnie minimalizowane.

5 Jeden z szeregowców maszerował doprawdy pokracznie, co zauważył akurat przejeżdżający dowódca Ośrodka Szkolenia Wojsk Lądowych. Kazał zatrzymać samochód, wysiadł i na cały plac wykrzyczał nazwisko dowódcy kompanii. Ten podbiegł, zameldował się i dostał "opr" za (komiczny mimowolnie!) krok marszowy owego szeregowca. Kiedy dowódca pułku odjechał, dowódca kompanii też wszystkimi siłami płuc wykrzyczał nazwisko dowódcy plutonu. Ów podbiegł, zameldował się i również został skrzyczany. Dowódca kompanii odszedł, zaś dowódca plutonu z nieskrywaną wściekłością wyryczał nazwisko pomocnika dowódcy plutonu. Jak wcześniej: zameldowanie się przełożonemu i następnie "opr". Dowódca plutonu odszedł, a jego pomocnik zawołał „Pluton! Zbiórka!". Kiedy przestraszeni szeregowcy karnie przed nim stanęli na baczność, ten rozbrajająco zapytał ich: „A kogo ja mam op...?". Znamienne: wszyscy trzej 'dziobacze' to byli żołnierze zawodowi, zaś pomocnik dowódcy plutonu - odbywającym roczną służbę wojskową absolwentem uczelni cywilnej (tzw. sorowcem). 
nich, a drudzy zawczasu już siedzieli w środku i to oni stanowili załogi). Od sorowców z Wałcza dowiedziałem się, że przed przyjazdem gen. Wojciecha Jaruzelskiego w koszarowej chlewni świnie myto szamponem.

Jak mawiali żołnierze: „Może być gówno, byle równo”. W Czarnem dowódca nakazał zerwać z drzew ostatnie jesienne liście, aby - kiedy przyjedzie inspekcja - żaden nie leżał na trawniku. Gdy na poligon w Drawsku Pomorskim przyjechały oddziały z dziesięciu jednostek, to pierwszego dnia wszystkie ustawiały łóżka w namiotach zgodnie z własnym poczuciem wojskowego porządku, a następnego dnia dziesięcioosobowa komisja wybrała najlepsze ustawienie i pozostałe dziewięć jednostek przestawiało łóżka tak, aby wszędzie stały identycznie. Na tym minęły dwa pierwsze dni poligonowych ćwiczeń. W owym 1978 roku wśród wierszyków powtarzanych przez szeregowych żołnierzy Ludowego Wojska Polskiego (Czarne) był ten: „Nam nie trzeba Bundeswehry, nam wystarczy minus cztery". Wiedzieli, jak krucha i pozorna była wojskowa siła porządku. By już nie wspomnieć o swoistej "logice".

Jednym ze wstydliwych problemów Polski zwącej się Ludową pozostawała higiena sanitarna. Zarówno wśród mieszkańców miast, jak i wsi. Cztery, z zachowaniem miejsko-wiejskiego parytetu, przykłady. W latach mojego dzieciństwa w miasteczku powiatowym (Pomorze Nadwiślańskie) było przyjęte, że mężczyźni w obecności kobiet i dzieci siusiali do kuchennych zlewów (nie: zlewozmywaków!). Kiedy w Domu Pracy Twórczej w Oborach Mieczysław Jastrun i Jan Himilsbach zamieszkali w jednym pokoju, wówczas padło pytanie: „Ustalmy, szczamy do umywalki czy nie?”. We wsi Fiałki (pod Górznem, a więc mniej więcej w tych okolicach, w których została znaleziona tytułowa instrukcja) na początku lat 8o. kierowca półciężarówki w Gminnej Spółdzielni Samopomoc Chłopska zawartość swego przydomowego szamba wylewał na warzywniak pod oknem swojej kuchni. W owej wsi z przydomowej piaskownicy o powierzchni około jednego metra kwadratowego wydobyłem dwa pełne wiadra śmieci.

6 Zajęcia w Studium Wojskowym UMK zainspirowały studentów do parodii wojskowej metodyki: „Dzida ogólnowojskowa składa się z przedzidzia, śróddzidzia i zadzidzia. Przeddzidzie składa się z przeddzidzia przedzdzidzia, śróddzidzia przeddzidzia i zadzidzidzia przeddzidzia. Śróddzidzie składa się z przeddzidzia śróddzidzia, śróddzidzia śróddzidzia i zadzidzia śródzidzia. Zadzidzie składa się z przeddzidzia zadzidzia, śróddzidzia zadzidzia i zadzidzia zadzidzia".

7 M. Łuczak „Rejs”, czyli szczególnie nie chodzę na polskie filmy, Prószyński i S-ka, Warszawa 2002, s. 57. 


\section{Nikiforma}

Właśnie na początku lat 8o. odgórnie nakazano, aby przy każdej zlewni mleka stanęły wychodki dla wozaków odbierających mleko od rolników. Przybytki te były wykonane z blachy (toteż latem niekiedy stawały się piekarnikami), miały z tyłu wysuwane, ,szuflady”, których zawartość na ogół wyrzucano gdzieś w pobliżu zlewni (przestrzeń współcześnie zwana otuliną wtedy pozostawała abstrakcją).W jednym z takich wychodków powieszono tę instrukcję]:

1. Ubikacja powinna być zawsze utrzymana w czystości.

2. Do muszli klozetowych i pisuarów nie należy wrzucać śmieci, szmat, niedopałków, zapałek ani resztek jedzenia.

3. Na muszlę klozetową nie należy wchodzić nogami, lecz siadać jak na krześle, całym ciężarem ciała, tak aby pośladki całkowicie i dokładnie przylegały do deski klozetowej.

Tułów powinien być wyprostowany, przy czym punkt ciężkości należy przenieść ze stóp na pośladki, kładąc ręce wzdłuż odpowiednich kolan. Siedzieć należy w taki sposób, ażeby kał wpadał do muszli, a nie na deskę. Jednocześnie należy starać się nie zmoczyć deski moczem, w tym celu należy przytrzymywać ręką narząd moczowy, skierowując go do muszli.

4. Przy korzystaniu z pisuaru należy podejść do niego jak najbliżej, nawet dotykając go lekko kolanami, pochylić się do przodu, wyjąć całkowicie narząd moczowy, lekko nachylając go w dół i oddać mocz aż do ostatniej kropli. Przed zakończeniem oddawania moczu nie należy odchodzić od pisuaru, rozbryzgiwać moczu po podłodze. W ten sposób podłoga wokół pisuaru będzie sucha.

W tym (kuriozalnym?) tekście ${ }^{8}$ czymś nieco zagadkowym pozostaje liczba mnoga: „muszle klozetowe i pisuary” - ostatecznie wychodki pozostawały raczej małymi budkami. Być może pluralia pośrednio wskazują na anonimowego autora: byłby nim ktoś usytuowany wyżej niż tylko w pojedynczej zlewni mleka (na szczeblu gminnym czy powiatowym, a może nawet wojewódzkim?) ${ }^{9}$.

8 Gwoli miejsko-wiejskiej sprawiedliwości należy przywołać choćby dwa przykłady jeszcze bardziej kompromitującej inwencji werbalnej: „zwis męski” [krawat] i „podgardle dziecięce” [śliniaczek].

9 "[W administracji] Pragnie się wyłącznie niskiego poziomu, a jeszcze niższy się akceptuje. Wskazówki, dawane przez drugorzędnego szefa i adresowane do jego trzeciorzędnych urzędników, mówią jedynie o minimum celów i zalecają bezskuteczne środki. Nie wymaga się wyższego poziomu kompetencji, ponieważ skutecznie działająca organizacja wymykałaby się spod kierowniczych możliwości szefa". C.N. Parkinson Prawo Parkinsona albo w pogoni za postępem, przeł. .. Kydryński, Książka i Wiedza, Warszawa 1983, s. 95. 
Wydane po raz pierwszy w 1982 roku Nikiformy to zbór "tekstów gotowych”, ,napisanych przez życie”. Edward Redliński: „Milion pop-utworów leży w skoroszytach, teczkach, kopertach - czeka, żółknie - aż zginie bezpowrotnie w regulaminowym przemiale, aż szczeźnie na wysypiskach..." ${ }^{\prime 10}$. Mniejsza tu o to, jak po niemal czterdziestu latach multimedia zwielokrotniają liczbę pop-utworów, ważniejsze pozostanie to, że zawieszona w wychodku zlewni mleka instrukcja ocalała i tym samym może stawać się przedmiotem uwagi. Także jako nikiforma - dwakroć swoista: 1. pochodząca nie jeszcze z lat 70. (swe reporterskie znaleziska Edward Redliński publikował od 1974 roku), lecz już z pierwszej połowy 8o. i poniekąd tym samym powstała w atmosferze lat stanu wojennego; 2. swoją gatunkową tożsamością samoistna wobec tych wypowiedzi, które wcześniej trafiały do rąk Edwarda Redlińskiego.

Spośród wielorakich tekstów, współtworzących gatunkowo „niezgodnie zgodne" Nikiformy, jeden wydaje się szczególnie bliski instrukcji. To Żyć do samej śmierci - prowadzony w sześćdziesięciokartkowym zeszycie w kratkę pamiętnik księgowej, która intensywną namiętność erotyczną splotła z... rachunkowością. Z jednej strony „wysokie” emocje - z drugiej „niskie” realia:

9.11.64. Poniedziałek. U mnie od 18 do 20 w łóżku (Fela za ścianą szatkowała kapustę)... 2 [razy]

4.1.65. Poniedziałek (u mnie) od 17.30 do 20.30, na kanapie po kolacji (nóżki na zimno, grzybki marynowane, sałatka i Szery Brandy, herbata z cytryną... 2 razy

14.7.68. Niedziela. Obchodziliśmy uroczyście IV rocznicę. O 16 zasiedliśmy do stołu - wódka wyborowa 0,5 l, serdelki ze świeżą kapustą, pomidory, ogórki ze śmietaną, byczki, herbata z cytryną. O 17 położyliśmy się wypocząć, do 19. [Stanisław] Bardzo namiętny w łóżku...2 razy 21.7.68. Niedziela, śliczna pogoda. [...] W domu nie było co wypić, więc [Stanisław] pojechał do siebie i przywiózł 0,25 wódki. A ja szykowałam kolację - zupa, kalafior, kurczaki, ogórki w śmietanie, grzyby duszone, a potem czarna kawa. Na fortepianie stały cudne białe mieczyki, a ja byłam w żółtej sukni.Zjedliśmy kolacjęi o 20 do łóżka.Za ścianą nikogo nie było... byliśmy sami. Wycałował mnie całą czule, a ja jego.Zrobiliśmy 1 raz dobrze, a potem zasnęliśmy. W nocy powtórzył jeszcze raz. Spaliśmy bardzo dobrze. Wyszedł ode mnie o 2.30 rano, juź świtało i poszedł do domu... 2 razy."

E. Redliński Kawa na ławę, s. 6. 
Ponadto całoroczne bilanse zbliżeń: 1964 roku - 44 razy, 1965 - 84 razy, 1966 roku - 43 razy, 1967 roku - 34 razy, 1968 roku - 27 razy $^{12}$.

Chociaż tytułowej instrukcji z efektem komicznym tego erotyczno-kulinarnego pamiętnika może trudno rywalizować, to jednak jako nikiforma przynajmniej w jednym wymiarze zdecydowanie przewyższa go, mianowicie analogicznie jak on jest samoistna oraz autentyczna, a zarazem przeważa nad nim swą funkcją użytkową: księgowa była egocentryczna, zaś autor instrukcji, nawet jeśli kierował się swoim dobrem kogoś odpowiedzialnego za stan higieny w wychodku czy też w wychodkach, to przecież zarazem mógł myśleć, że działa również dla dobra społecznego, to znaczy i pracowników zlewni mleka, i konsumentów wyrobów przemysłu mleczarskiego.

Habent sua fata libelli. Chociaż losy Nikiform oraz instrukcji mają swe początki w latach 8o., to jednak czytelnicze żywoty wiodły odmienne.

Książka ukazała się po raz pierwszy w 1982 roku, w środku stanu wojennego. Był to czas ograniczenia głosu tych, którzy mogliby opisać Nikiformy adekwatnie do ich wartości i historycznoliterackiej rangi - zamknięto wtedy wszakże wiele czasopism, a ocena książek przypadła recenzentom z „Trybuny Ludu”. W przypadku recepcji Nikiform dało to efekt przewidywalny: utwór programowo odrzucający model tradycyjnie pojmowanej literackości uznano za nieudolne zastosowanie nieopisanego bliżej wzoru prozy narracyjnej. ${ }^{13}$

Tymczasem instrukcja pozostawała tekstem szerzej nieznanym aż do 2005 roku, kiedy można było o niej przeczytać w „Tekstach Drugich”. W tej pierwszej poświęconej jej publikacji materii ściśle literaturoznawczej było stosunkowo niewiele, szerzej została podjęta w drugiej publikacji, tzn. w jednym z rozdziałów książki Ciało - płeć - kultura. Z kolei w tej - trzeciej - publikacji problematyka literackości instrukcji będzie już pierwszoplanowa.

Przyjąwszy (jednak dyskusyjne) założenie, że wiedza o autorze jednak należy do literaturoznawstwa, dochodzimy do wstępnego pytania o autora

12 Na wręcz humanitarną wymowę zdawałoby się jedynie kuriozalnego pamiętnika erotycznie rozbudzonej księgowej w wieku już emerytalnym zgodnie wskazują Edward Redliński (Kawa na ławę, s. 7) oraz Anna Mach (PRL-owskie ready-mades Edwarda Redlińskiego, w: (Nie)ciekawa epoka? Literatura i PRL, red. H. Gosk, Dom Wydawniczy Elipsa, Warszawa 2008, s. 349-350). 
instrukcji. Kim on bowiem jest? Półinteligentem czy mistrzem paraliteratury użytkowej? Półinteligentem - w swojej kulturowej kompetencji przyswoił sobie wszak z pewnością językowo sprawną polszczyznę, a zarazem popełnił wielki błąd stylistyczny? Mistrzem paraliteratury użytkowej - jednocześnie podjął konwencję urzędowej polszczyzny i jej świadomie zamierzoną parodią ośmieszył nie siebie, lecz tych wszystkich przedstawicieli władzy, o których politycy i publicyści twierdzą, że „mówią co wiedzą, a nie wiedzą, co mówią”. Anonimowość autora instrukcji nakazuje zawczasu poniechać pytania o jego społeczny status oraz nim uwarunkowaną intencję: dowieść urzędniczej kompetencji czy też "grać” tekstem, który “powierzchniowo' może wydawać się wypowiedzią wręcz osobiście zaangażowaną, zaś 'głębinowo' może być czytany jako ośmieszenie iluzorycznej władzy urzędniczego słowa pisanego - co wskazuje na pokrewieństwo z antologią Redlińskiego:

W Nikiformach śmieszy przede wszystkim język, który w głównej mierze stanowi dziwaczny w realizacji kompromis mowy potocznej z urzędniczą frazeologią. Jednakże ten kompromis zawarty w języku, najdobitniej skompromitowany wtedy w nowomowie, odzwierciedla różnorakie codzienne kompromisy zawierane w konkretnych sytuacjach [...]. To właśnie powoduje, że wymowa tych tekstów musi być niejednoznaczna, bowiem ukazują one uwikłanie ludzi w wieloznaczną właśnie sytuację komunikacyjną. ${ }^{14}$

Zarazem jeśli przyjąć wszak niepodważalne założenie, że mowa poprzedza pismo, to czymś niedocieczonym i wysoce prawdopodobnym pozostaną wcześniejsze niż instrukcja „pyskówki” jej autora z wozakami - przynajmniej w poważnym zakresie daremne i dlatego zastąpione czy też przynajmniej dopełnione instrukcją. Wątpliwa skuteczność prawdopodobnych „pyskówek" i pisemnie faktycznej instrukcji pozostawała uwarunkowana tym, że efektywne porozumienie między jej autorem i adresatami byłoby z trudem osiągalne, o czym rozstrzygała różnica dwóch poziomów kultury sanitarnej: innego w wiejskim obejściu ${ }^{15}$, innego wokół zlewni mleka (znamiennie

14

15

A. Mach PRL-owskie ready-mades Edwarda Redlińskiego, s. 344-355.

"O tym, że wychodek był zbytkiem, że z wypróżnianiem się nie łączono większego poczucia wstydu, świadczy jeszcze samo budowanie wychodków: bez przedniej ściany, bez drzwi lub z drzwiami do połowy wysokości ściany, często także bez zadaszenia. Powszechniejsze z czasem i bardziej staranne budowanie sraczy, w końcu ubikacji wewnątrz domu, dyskretnych 
brzmią słowa jednego z chłopów o przybyłej do Taplar nauczycielce: „Jak jej w chlewie kiepsko, niechaj kroi do waliski!"16). Problem nie wiązał się bynajmniej z przeciwstawianiem wsi i miasta - kiedy w 1980 roku pułkownik Zbigniew Skoczylas kierował obozem taternickim w Morskim Oku, przy wychodku kazał zawiesić tablicę z tym nakazem: „Wysrałeś się - umyj ręce” (tu należy dopowiedzieć: przynajmniej znaczącą część taternickiego środowiska stanowili... nauczyciele akademiccy).

Niemal cztery dziesięciolecia - oddzielające rok pierwszego wydania Nikiform od roku, w którym ta publikacja jest czytana - to dekady, po których przeminięciu literaturoznawcom jeszcze trudniej niż ówcześnie przyjmować jakąkolwiek „normę” prozy narracyjnej. Dziś jeszcze mocniej dostrzegana niemożność wskazywania granic wytyczających jej zakres sprzyja poszukiwaniom literackości w instrukcji niejako wbrew temu, że jako „czysty fakt” prymarnie społeczny, a jedynie wtórnie paraliteracki o jakiejkolwiek fikcji czy chociażby „fabularnym potencjale”"17 nie pozwala mówić, przy czym jej na ogół poprawna polszczyzna jednak powinna zostać określona jako przekreślający stosowność błąd stylistyczny: z pewnością „niska” materia wypowiedzi i przynajmniej „średnie”, a może nawet „wysokie” (gdyż urzędowe) wysłowienie relacji adekwatnej nie współtworzą.

Co więcej i niejako co gorsza dla literackości instrukcji,jej komizm pozostawał wręcz tragikomiczny: jedynie czytana jako sztuka czy też tylko „sztuka” wytwarzania sugestywnych w ich obrazowości przedstawień słownych mogła i wciąż może bawić przeciwieństwem powagi wysłowienia i (przynajmniej

miejsc dla załatwiania potrzeb fizjologicznych, dowodzi przemiany obyczaju, łączenia z tymi czynnościami większej intymności, o nabywaniu wobec nich, silniejszego niż dotąd, poczucia wstydu i wstrętu". A. Libera Rzyć, aby żyć. Rzecz antropologiczna w trzech aktach z prologiem iepilogiem, Liber Novum, Tarnów 1995, S. 156.

Cyt. za: tamże, s. 152.

„Recenzenci [Nikiform], nie bacząc na kontekst i funkcję słowa, które zgodnie z zamysłem autora ustanawiają literackość utworu, bezradni wobec «czystego faktu», zastępującego spodziewaną opowieść, ogłosili kategoryczny werdykt, że «to nie jest literatura». Prawdziwa literatura operuje bowiem polszczyzną literacką, a skopiowane w Nikiformach grypsy więzienne cechuje, co zdumiewające, nieporadność stylistyczno-językowa. [...] Powodem zarzutów jest również brak fabularnego potencjału językowych autentyków. [...] Poza kryterium urody wypowiedzi i podatności historii na fabularyzowanie zwrócono również uwagę na społeczną użyteczność utworu. Jej wskaźnikiem byłyby walory poznawcze i przekaz, których jednak krytycy nie dopatrzyli się w tekście. [...] Nikiformy nie spełniły zatem żadnego warunku tekstu wartościowego spośród tych, które przewiduje szablon oceny dzieła literackiego". M. Bukowiecka Antyliterackie, a więc literackie, s. 327-328. 
dla ludzi zdrowych) nieco komicznej przyziemności wypróżniania się - tymczasem powinna być czytana jako wręcz naturalistyczna „literatura faktu”.

Jedną z najsłynniejszych, a zarazem szczególnie prowokacyjnych ekspozycji Marcela Duchampa była, wystawiona w 1917 roku, „Fontanna” - pisuar (nie zaś, jak to bywa przyjmowane, sedes). Jakiekolwiek by były wspólne i rozłączne cechy fontann i pisuarów, należy podkreślić, że wystawa Stowarzyszenia Artystów Niezależnych w Nowym Jorku oraz wychodek podbrodnickiej zlewni mleka to miejsca nieporównywalne również w aspekcie stanowionym przeciwieństwem Duchampa „sztuki [dosłownie] czystej” i 'sztuki [dosłownie] brudnej' (w wychodku wymiocin apriorycznie wykluczyć nie można). Świat przedstawiony instrukcją jest współtworzony przez dwa przeciwne światy: lekturowo i intencjonalnie - czysty, doświadczalnie i tym samym realnie - śmierdzący fekaliami (vide przynajmniej niektóre toalety w pociągach).

Instrukcja z powodu jej niemal bezbłędnej i przecież płynnej polszczyzny może być postrzegana jako wypowiedź przynajmniej po części przecząca poetyce nikiformy.

Miarą wartości literackiej [Nikiform] jest przy tym [tzn. przy intertekstualnych relacjach wewnątrz jakże zróżnicowanego zbioru - przyp. K.O.] nie kunszt, jak w przypadku twórczości klasycyzującej, lecz dobrze wyeksponowana niedoskonałość. Wypowiedzi zebrane w Nikiformach nie byłyby literacko interesujące, gdyby stanowiły wzorową postać swego gatunkowego inwariantu. Artystyczny efekt spięcia i iskrzenia między słowami [...] wytwarzają te elementy wypowiedzi, które mącą jej stylistyczną jednolitość czy wyłamują się z modelu gatunkowego, w jaki wpisuje się tekst. ${ }^{18}$

Tymczasem instrukcja przeczy nikiformowej „dobrze wyeksponowanej niedoskonałości”. Jedyna jej językowa ułomność to słowa: „punkt ciężkości należy przenieść ze stóp na pośladki, kładąc ręce wzdłuż odpowiednich kolan". Te ostatnie - „odpowiednie kolana" - nawet jeśli mogą być trochę niezrozumiałe, to przecież z łatwością można domyślać się, że chodzi o to, aby nie krzyżować rąk. Co jednak najważniejsze: instrukcję cechuje poprawna składnia i bezbłędna interpunkcja - ta druga zaś szczególnie wymaga zrozumienia logiki budowy zdań dzielonych przecinkami. Innymi słowy: na poziomie gramatycznym

18 Tamże, s. 334. 
instrukcja jest wypowiedzią zachowującą „stylistyczną jednolitość, natomiast „artystyczny efekt spięcia i iskrzenia między słowami” należy do materii jedynie i zarazem aż stylistycznej: „sztuczna” mowa contra „naturalna” fizjologia.

\section{Genologia retoryczna: wymowa pokazowa}

Zważywszy na językową „grę” czy też może raczej „zabawę” autora instrukcji, można przyjmować, że jej gatunkową tożsamość najtrafniej pozwoli wskazać genologia lingwistyczna ${ }^{19}$. Ta jednak nie jest bezalternatywną optyką. Kilka lat temu, w badaniach literatury staropolskiej, zwrócono uwagę „na retoryczny system gatunkowy jako niezwykle ważny czynnik modelujący kształt tekstu poetyckiego"20 . Również dla rozpoznania gatunkowej postaci instrukcji być może optymalna będzie genologia retoryczna - ta jakkolwiek wcześniej pozostawała poza terminologią historyków krasomówstwa, to jednak (przyjął Roman Krzywy) nic nie stoi na przeszkodzie, aby właśnie tak nazywać ten dział teorii retorycznej, który zajmował się rodzajami mów²1. Tak więc - zapytajmy - czym będzie instrukcja czytana w kontekście genologii retorycznej?

Klasyczna definicja retoryki - Kwintyliana Ars bene dicendi - może zwodzić jej rozumieniem uwarunkowanym znaczeniami polskich słów w potocznym wysłowieniu. W teorii retorycznej bowiem „sztuka” była rozumiana również jako perswazyjne rzemiosło, „dobre” wiązało się z walorami estetycznymi i etycznymi, a „mówienie” powinno być zaprzeczeniem tego, co może być nazywane wielomówstwem, mową trawą czy też paplaniną. Z tą Kwintyliańską definicją Ars bene dicendi splecione były trzy podstawowe funkcje wymowy, w traktatach i podręcznikach zazwyczaj wyrażane za pomocą łacińskich bezokoliczników: docere, movere, delectare. To doprawdy podstawowe wyróżnienie owych funkcji okaże się nie tyle zawodne, ile zawikłane wówczas, kiedy zostanie odniesione do wychodkowej instrukcji.

1. W Retoryce opisowej przeczytamy:

Docere zmierza do „wiary” (ad fidem), czyli do pozyskania zgody słuchacza, który ma uwierzyć mówcy, poprzez „konieczność” (necessitas, co znaczy

19 Pars pro toto: B. Witosz Genologia lingwistyczna. Zarys problematyki, Wydawnictwo UŚ, Katowice 2005; Polska genologia lingwistyczna, red. D. Ostaszewska, R. Cudak, PWN, Warszawa 2008. R. Krzywy Poezja staropolska wobec genologii retorycznej. Wprowadzenie do problematyki, Wydział Polonistyki UW, Warszawa 2014, s. 9. 
także: coś niezbitego, nie do podważenia) przy zastosowaniu środka stylistycznego zwanego acumen. Ten termin w historii stylistyki bywa różnie komentowany - nieraz znaczył tyle, co „dowcip” lub „koncept”, ale jego klasyczne rozumienie jest inne: dosłownie „ostrze”, ,wierzchołek", a w zastosowaniu do stylu niskiego acumen oznaczał raczej ostrość i jasność sensu, tj. unikanie wieloznaczności $[\ldots]^{22}$

Jakiż styl należy przypisać instrukcji? Niepodobna rozstrzygnąć. Wysoki we własnym mniemaniu przedstawiciela władzy urzędniczej? Niski w przekonaniu osób bezpośrednio niezaangażowanych w konflikt związany z wychodkową higieną sanitarną? Zarazem jak „uwierzyć mówcy”, kiedy argumentacja została pominięta milczeniem? Zamiast niej znajdujemy poniekąd apodyktyczne twierdzenie: „Ubikacja powinna być zawsze utrzymana w czystości”. Tak więc przychodzi w instrukcji daremnie szukać istoty perswazji - nią bowiem pozostawała argumentacja (a nie przymus fizyczny czy przekupstwo). Co jeszcze ważniejsze, dla wozaków „dowcip” czy też „koncept” instrukcji najprawdopodobniej czy też tylko przeważnie był niedostępny z dwóch powodów: mniejsza o ich wysoce prawdopodobny wtórny analfabetyzm, ważniejsze bowiem co innego: nawet jeśli byłaby czytana ze zrozumieniem, to jako "gra" z urzędniczym wysłowieniem wymagałaby takiej kultury literackiej, która na ogół przewyższała tę przez wozaków wynoszoną ze szkoły podstawowej.

2. Jeśli movere wiąże się z „poruszeniem” poprzez „zwycięski skutek” przy wykorzystaniu silnych środków perswazji ${ }^{23}$, to przecież skierowana do wozaków instrukcja mogłaby być jedynie słabą wypowiedzią - próżno byłoby porównywać jej (w skali Polski) mikroskopijne oddziaływanie z tymi wszystkimi czynnikami, które przemieniały wieś po transformacji ustrojowej 1989 roku (znamienne: jeszcze w latach 8o. rolnicy nawet z wdzięcznością pozwalali mieszczanom zbierać z pól kamienie, te wszak niszczyły maszyny rolnicze, jednak z czasem sami zaczęli postrzegać je jako ozdobę przydomowego otoczenia).

3. Po raz trzeci zwróćmy się do Retoryki opisowej: delectare prowadzi do „zjednania” słuchacza poprzez „przyjemność” przy wykorzystaniu „łagodnych”

\footnotetext{
22 J. Ziomek Retoryka opisowa, Ossolineum, Wrocław 1990, s. 58.

23 Tamże.
} 
środków stylistycznych ${ }^{24}$ - tymczasem instrukcja jako parodia urzędniczego wysłowienia była wypowiedzią może doprawdy morderczą i jednocześnie, nawet przeczytana przez wozaków, pozostawała wyłącznie elitarną grą językową (zabawą zarezerwowaną dla samego autora, zapewne osób bliskich mu w pracy czy rodzinnie, z pewnością dla odkrywcy instrukcji Krzysztofa Lewandowskiego i jej „kustosza” Marii Lewandowskiej, tzn. on ją znalazł, ona - ocaliła wywieszeniem w swoim leśnym wychodku), a także dla badaczy nikiform.

Jednakże stwierdzenie, że instrukcja ciąży ku rodzajowi pokazowemu, jeszcze nie rozstrzyga o jej gatunkowym statusie. Byłaby bowiem pochwałą czy naganą? Pytanie błędnie sformułowane, ponieważ obydwa w teorii przeciwstawne gatunki jawią się jako w niej splecione.

O ile pierwsze zdanie instrukcji brzmi niczym pochwała higieny sanitarnej, to następne są już opisem takiego stanu rzeczy, który powinien zostać potępiony. Poniekąd trudno oddzielić, co jest czym: realia i porządek powinności zarazem przeczą sobie oraz 'przez zaprzeczenie' konstytuują siebie. Tak genologia retoryczna okazuje się czymś, co nie pozwala rozstrzygająco wypowiedzieć się o gatunkowym statusie instrukcji. Jeśli bowiem nawet przyjmiemy, że należy do wymowy pokazowej i jest hybrydą dwóch jej gatunków (pochwały [czystości] i nagany [brudu]), wówczas przyjdzie nam zmierzyć się z tymi słowami Retoryki literackiej:

Dla mowy, rozumianej jako pokaz [perswazyjnego kunsztu], najbardziej odpowiednie pozostają te sprawy, które są najbardziej stosowne dla samego pokazu, tj. przedmioty piękna. Pokaz sztuki oratorskiej jest więc przedmiotowo zorientowany na pokaz piękna danej materii sprawy, która to materia zostaje opisana i pochwalona. Pochwała piękna jest główną funkcją epideiktycznej retoryki. ${ }^{25}$

Jednakże wychodkowe realia piękne nie były ${ }^{26}$, a ówcześnie czystość przynajmniej na jakiś czas była z trudem wyobrażalna ${ }^{27}$.

24 Tamże.

25 H. Lausberg Retoryka literacka. Podstawy wiedzy o literaturze, przeł., oprac., wstęp A. Gorzkowski, Homini, Bydgoszcz 2002, s. 135. Por. P. Kowalski O tym, co nieuniknione: ekskrementy i defekacja, w: Ciało cielesne, red. K. Konarska, Wydawnictwo UWr, Wrocław 2011, s. 19-20.

27 Do małomiasteczkowej szkoły podstawowej chodziłem jeszcze w latach 60.: w ubikacji uczniowie rywalizowali o to, który z nich zdoła nasiusiać na... sufit - wielorakich efektów sanitarnych 
W tak swoistej sytuacji komunikacyjnej, jaką stwarzał problem z przestrzeganiem wszak elementarnych zasad higieny w wychodku zlewni mleka, zapewne istotną okolicznością mogło pozostawać, jeśli już nie biurokratyczne przekonanie o skuteczności instrukcji (ta byłaby wypowiedzią kogoś zdesperowanego daremnością dotychczasowych starań o czystość?), to może przynajmniej znamienna dla socrealistycznej nowomowy postawa magiczna: jeśli słowa zaklinają rzeczywistość i tym samym poniekąd stwarzają lub unieważniają świat, wówczas urzędowe nakazy i zakazy powinny jakby same $\mathrm{z}$ siebie przemieniać urągający elementarnej higienie stan rzeczy (punkty 2-4) w stan powinności (punkt 1).

Jeśli - za Arystotelesem - przyjmiemy, że retoryka jest sztuką przekonywania jedynie za pomocą argumentów, wówczas należy przyjąć, że instrukcja najprawdopodobniej stała się komunikacyjną katastrofą: pominięcie pełnym milczeniem jakiejkolwiek argumentacji wskazującej na konieczność zachowania nawet tylko elementarnej kultury sanitarnej czyniło z niej przekaz dla adresatów nieprzekonywający ${ }^{28}$, a przynajmniej wysoce prawdopodobny wtórny analfabetyzm wozaków sprawiał, że stawała się wypowiedzią wręcz niezrozumiałą (słowa powinny być zastąpione obrazkami?). Należy jeszcze dodać, że ówczesny deficyt papieru toaletowego ${ }^{29}$ sprzyjał innemu wykorzystaniu jej niż jako przedmiot lektury. Jednak niezależnie od tej komunikacyjnej katastrofy instrukcja w jej 'nikiformicznej', a więc w (anty?)literackiej postaci (nowomowa ${ }^{30}$ ?), może być interesująca.

nie trzeba werbalizować. Jeszcze w latach 70. w Białymstoku przy głównej ulicy Lipowej znajdował się punkt reparacji pończoch - na kawałku tektury napisano „Pończochy przyjmujemy tylko prane" (K. Masłoń Bananowy song. Moje lata 70., Świat Książki, Warszawa 2006, s. 62).

"Nie tylko w miarę rozwoju rozumienia to, co najbardziej w nim głębokie i złożone staje się niedostępne dla bardziej prymitywnych formacji świadomości, ale i na odwrót, wyższy rozwój oznacza po części brak rozumienia tego, co na niższym poziomie (oto jak w prosty sposób można ukazać, że także wyższa inteligencja może bywać ogłupiająca, dezorientująca...). Ten nieuchronny proces można określić jako wzrost przepaści umysłowych, których praktycznym przejawem jest to, że w każdym rozumieniu występuje moment nieporozumienia". J. Dobrowolski Filozofia głupoty, PWN, Warszawa 2007, s. 181.

29 Znamienny dla pierwszej połowy lat 8o. brak papieru toaletowego w "Dzienniku Telewizyjnym" był wyjaśniany następująco: „Trzeba wziąć pod uwagę, że w ostatnich latach z papieru toaletowego korzysta w coraz większym stopniu wieś". Za: W. Kot PRL. Czas nonsensu. Polskie dekady. Kronika naszych czasów 1950-1990, Wydawnictwo Publicat, Poznań 2007, s. 219. czątkowo po rosyjsku ciężki styl administracyjny carskiej biurokracji. W latach dwudziestych chętnie się wykpiwało ten nowy, rozpowszechniony przez prasę język, który Zoszczenko na- 
W przypisach do pierwszej księgi Retoryki Henryk Podbielski wyjaśnił spójność załączonej przez niego tabeli:

Dokonana przez Arystotelesa klasyfikacja wymowy uwzględniająca również odpowiedni dla każdego rodzaju czas gramatyczny oraz bezpośredni cel przy jednoczesnym podziale każdego rodzaju na dwa przeciwstawne gatunki świadczy o uniwersalności jego teorii retorycznej, która może dotyczyć wszelkiej wypowiedzi jako środka międzyludzkiej komunikacji. ${ }^{31}$

Ta klasyfikacja została unaoczniona schematem:

\begin{tabular}{|c|c|c|c|c|}
\hline Rodzaj: & Gatunek: & Czas. gram.: & Cel bezpośredni & Cel ostateczny \\
\hline $\begin{array}{l}\text { I doradczy } \\
\text { II sądowy } \\
\text { III popisowy }\end{array}$ & $\begin{array}{l}\text { zachęta } \\
\text { odradzanie } \\
\text { oskarżenie } \\
\text { obrona } \\
\text { pochwała } \\
\text { nagana }\end{array}$ & $\begin{array}{l}\text { przyszły } \\
\text { przyszły } \\
\text { przeszły } \\
\text { przeszły } \\
\text { teraźniejszy } \\
\text { teraźniejszy }\end{array}$ & $\begin{array}{l}\text { pożytek } \\
\text { szkoda } \\
\text { sprawiedliwość } \\
\text { niesprawiedliwość } \\
\text { szlachetność } \\
\text { niegodziwość }\end{array}$ & $\begin{array}{l}\text { słuchacz } \\
\text { słuchacz } \\
\text { słuchacz } \\
\text { słuchacz } \\
\text { słuchacz } \\
\text { słuchacz }^{32}\end{array}$ \\
\hline
\end{tabular}

Takie retoryczne dystynkcje mogą wskazywać genologiczną tożsamość instrukcji w co najwyżej umiarkowanym zakresie:

- nawet jeśli instrukcja należy do wymowy doradczej i zachęca do zachowania elementarnej kultury sanitarnej, to przecież argumentacja pozostaje wyłącznie domyślna, próżno bowiem szukać jakiegokolwiek uzasadnienia zakazów i nakazów;

zywał «językiem małp». W tym samym czasie w Polsce używano zwrotu «zastygły język». [...] Mówienie o stylu w odniesieniu do «drewnianego języka» jest rzeczą niemalże komiczną. Jeśli styl traktować jako indywidualne piętno, które każda jednostka odciska na języku, to dyskurs komunistyczny należałoby określić przede wszystkim jako nie-styl. [...] Powstaje prawdziwie kolektywny sposób pisania, i to niezależnie od tego, jaki temat ma być poruszony". F. Thom Drewniany język, przeł. I. Bielicka, Wydawnictwo CDN, Warszawa 1990, s. 7-31.

H. Podbielski Przypisy do „Retoryki”, w: Arystoteles Retoryka. Poetyka, przekład, wstęp, koment. H. Podbielski, PWN, Warszawa 1988, s. 374.

Tamże. Na marginesie: ta zasadnicza dla teorii retorycznej tabela zawiera oczywiste błędy, ponieważ w wymowie doradczej celem bezpośrednim jest nie szkoda (lecz jej uniknięcie), w wymowie sądowej celem obrony pozostaje sprawiedliwość, zaś celem nagany będzie dowiedzenie niegodziwości i tym samym - co ważniejsze - obrona szlachetności. 
- instrukcja co prawda może być czytana jako oskarżenie nagannego stanu rzeczy i obrona oczekiwanego stanu kultury sanitarnej, jednak o wymowie sądowej trudno tutaj mówić, gdyż dominuje czas teraźniejszy, a nie przeszły;

- może należałaby więc do wymowy popisowej? - ale szlachetność faktycznie byłaby walorem zachowania elementarnej kultury sanitarnej? W kontekście genologii retorycznej instrukcja jednak nie jest gatunkową hybrydą, ponieważ można wskazać jej gatunkowa dominantę - za autorem Retoryki literackiej:

Przedmiot mowy, który rozpatrywany jest poważnie w genus iudicale i genus deliberativum, nie ma dla słuchacza [wypowiedzi należącej do rodzaju pokazowego - przyp. K.O.] istotnego znaczenia; jest on traktowany po prostu jako możliwość pokazowego ćwiczenia w sztuce oratorskiej, podczas gdy w genus iudicale i genus demonstrativum znaczenie mowy wypływa wyłącznie z jej przedmiotu. [...] Genus ten [tj. demonstrativum - przyp. K.O.] pielęgnuje l'art pour l'art („sztukę dla sztuki”): mówca pokazuje swą sztukę oratorską wobec zaproszonej publiczności, która nie wyraża praktycznego sądu odnoszącego się do zawartości mowy, lecz ocenia (podziwia) sam artyzm. ${ }^{33}$

Ta istotna różnica między wymową sądową i doradczą a pokazową pozwala rozpoznać retoryczną tożsamość instrukcji: niezależnie od jedynie prawdopodobnej intencji twórczej jej autora - zasadniczo należy do wymowy pokazowej, ale zarazem jednak splata się z wymową doradczą i sądową. Najistotniejsze dla jej gatunkowego statusu pozostaje to, że 'niskiej' czy też 'średniej' materii instrukcji należy przypisać znaczenie wyłącznie umiarkowane, ponieważ brak elementarnej kultury sanitarnej stał się sposobnością, aby nieznany autor (mimowolnie?) mógł wykazać się swoistym urzędniczym talentem pisarskim. Komuż jednak wychodkowa sztuka oratorska została pokazana? Samemu autorowi? Może jeszcze jego znajomym w pracy czy też bliskim w domu, jednak zdawałoby się zasadnicza społeczność czytelnicza pozostawała zaledwie czymś znikomym zarówno za sprawą wysoce prawdopodobnego wtórnego analfabetyzmu wozaków, jak i niedostatecznego poziomu ich kultury literackiej, by już nie wspomnieć o ówcześnie permanentnym braku papieru toaletowego. 


\section{Gatunek}

Gatunek jest tu rozumiany za Grzegorzem Grochowskim, a więc będzie:

traktowany jako utrwalony sposób działania za pomocą języka, związany ze stypizowaną sytuacją społeczną [...]. [...] o fortunności identyfikacji gatunkowych zaczyna decydować przede wszystkim możliwość włączenia danej wypowiedzi do strumienia interakcji społecznych i odniesienia jej treści do rozpoznawalnych pól asocjacyjnych, natomiast znacznie skromniejszą rolę przyznaje się kombinatoryce określonych składników i cech, których funkcje mogą być modyfikowane w toku interpretacji poprzez doraźnie uzgadniane korekty, parafrazy, substytucje, amplifikacje czy uzupełnienia. Koncepcja tekstu jako jednostki dyskursu pozwala więc nadal uznawać intencje podmiotu oraz ich formalne korelaty za istotne momenty procesu sygnifikacji, jednak żadnemu z tych elementów nie przypisuje rozstrzygającej roli w ustalaniu atrybucji gatunkowych, kładąc raczej nacisk na regulujące oddziaływanie uwarunkowań pragmatycznych. ${ }^{34}$

Obiekt znaleziony $w$ panoptykonie. Książki skarg i wniosków jako ready-made - to tytuł jednego z rozdziałów książki Grzegorza Grochowskiego Pamięć gatunków. Ponowoczesne dylematy atrybucji gatunkowej. Między sklepową książką skarg i wniosków a instrukcją można wskazać liczne analogie:

- obie to anonimowe zapisy - przeniesione w przestrzeń komunikacji swoiście artystycznej;

- są nikiforycznymi werbalizacjami przeciwieństw między stanem realnym (braki zaopatrzenia - brud) a pożądanym (pełne zaopatrzenie - czystość);

34 G. Grochowski Obiekt znaleziony w panoptykonie, s. 191-192. W programie telewizyjnym "Teleświat" (nr 2009/14; 3.04.-9.04.2009) na s. 21 znalazłem tekst opatrzony tytułem Kto wymyśla te instrukcje? Pod tytułem lead: Kota nie wkłada się do lodówki, telefonu nie suszy się w mikrofali, a zapalniczki nie używa się w kieszeni. To wydaje się oczywiste. Dlaczego więc producenci czują się w obowiq̨zku ostrzegać nas przed użyciem wszystkich tych sprzętów w sposób, jaki chyba nikomu nie przyszedłby na myśl? Jako przykłady kuriozalnych instrukcji podano:

- instrukcja obsługi żelazka ostrzega: „Nie prasować ubrań na ciele”,

- w instrukcji pralki automatycznej znajdziemy zakaz: „Nie wkładać dzieci do bębna”,

- na papierze toaletowym przeczytamy ostrzeżenie: „Aby uniknąć ryzyka uduszenia, przechowuj z dala od dzieci",

- spłuczka publicznej toalety przy Wielkim Kanionie informuje: „Woda niezdatna do picia”,

- na suszarce do włosów ostrzeżenie: „Nie używać podczas snu”. 
- obie mogą być wiązane z magiczną postawą wobec języka i stanowić element zaklinania rzeczywistości, ono zaś może łagodzić „ogólne poczucie bezradności poprzez kanalizowanie doraźnych frustracji”35;

- mniej lub bardziej iluzorycznie mają dyscyplinować (sprzedawców poprzez zawieszenie książki skarg i wniosków ${ }^{36}$ oraz wozaków poprzez wywieszenie instrukcji w wychodku);

- już sama zmiana ich pierwotnego kontekstu (życiowego) na wtórny (przynajmniej poniekąd artystyczny) radykalnie zmienia wymowę słów ${ }^{37}$;

- obie należą do form tekstowych znamiennych dla semiosfery PRL ${ }^{38}$;

- dopiero ponowoczesność stała się czynnikiem sprzyjającym poważniejszemu zainteresowaniu się nimis ${ }^{39}$.

Wskazywanie analogii między sklepową książką skarg i wniosków a wychodkową instrukcją wiąże się z dostrzeganiem przeciwieństw:

- sklepowe „niezwykłe zagęszczenie błędów językowych, świadczące o niskim poziomie komunikacyjnych kompetencji większości społeczeństwa"40 contra w zasadzie bezbłędna kultura wychodkowego wysłowienia;

- status obligatoryjny ${ }^{41}$ contra status spontaniczny;

G. Grochowski Obiekt znaleziony w panoptykonie, s. 195.

„Biorąc zaś pod uwagę rutynową niemal powtarzalność skarg na niedobory towarów, brud i lekceważące zachowanie personelu, należy wątpić w praktyczną skuteczność podobnych interwencji, przypominających raczej kompensacyjne odgrywanie życzeniowych scenariuszy i szukanie [...] «spazmatycznych dowodów na własne istnienie»". G. Grochowski Obiekt znaleziony w panoptykonie. Książki skarg i wniosków jako ready-made, s. 184.

37 "Jedną z najpoważniejszych przeszkód, z jakimi boryka się rygorystyczna analiza językowa literatury, jest kontekst. Wszelkie badania tekstu literackiego, które trzymają się czystego formalizmu, poprzestając na składni, semantyce i słowach wydrukowanych na papierze, są skazane na porażkę. Wnioski z wąsko pojmowanej analizy strukturalistycznej na ogół okazują się mało użyteczne dla literaturoznawców". P. Stockwel Poetyka kognitywna. Wprowadzenie, Universitas, Kraków 2006, s. 129.

"[W latach siedemdziesiątych] zachodnim turystom odwiedzającym Kraków pokazywano po tradycyjnym zestawie zabytków babcię klozetową, która w czasie dyżurów grała na skrzypcach". W. Kot PRL. Czas nonsensu. Polskie dekady. Kronika naszych czasów 1950-1990, Publicat, Poznań 2007. Tamże, s. 191.

Por. G. Grochowski Obiekt znaleziony w panoptykonie, s. 177.

Tamże, s. 180 .

Tamże, s. 185. 
- klienci wpisujący swe skargi i wnioski z ich stereotypowymi wyobrażeniami wypowiedzi urzędowej contra anonimowy autor instrukcji z jego (świadomie czy mimowolnie?) szyderczo realną wypowiedzią urzędową.

Problemem liczebności tekstów. Obowiązkowe w każdym sklepie książki skarg i wniosków poniekąd były niezliczone, tymczasem instrukcja pozostała niemal pojedyncza. To znaczy: wiosną 2010 roku po zajęciach, na których omawiałem ową unikatową instrukcję z podbrodnickiej zlewni mleka, jeden z studentów przyniósł mi wydruk podobnej instrukcji (znalezionej w Internecie - opatrzonej ilustracją: na sedesie siedzi ubrana w spodnie i bluzę małpa, w lewej łapie trzyma do połowy obranego banana, w prawej rączkę spłuczki). Poprzestanę na zacytowaniu owej instrukcji:

1. Ubikacja powinna być zawsze utrzymana w czystości, a użytkownik po wypróżnieniu powinien być zadowolony.

2. Do muszli nie wrzucamy podpasek, portfeli, niedopałków, szmat, resztek posiłków konsumowanych w toalecie.

3. Na muszlę klozetową nie wchodzimy nogami, lecz siadamy wygodnie całym ciężarem tak, aby pośladki całkowicie przylegały do deski klozetowej.

4. Po przybraniu pozycji siedzącej należy wyprostować tułów, po czym środek ciężkości ze stóp przenieść na pośladki, symetrycznie względem osi podłużnej muszli klozetowej.

5. Aby nie zabrudzić muszli klozetowej lub posadzki, kał oddawać celując w środek muszli.

6. Przy oddawaniu moczu narząd moczowy przytrzymać ręką lub pensetą i kierować strumieniem jak sikawką strażacką w kierunku środka muszli.

7. Po oddaniu kału podetrzeć się ruchem posuwistym w jednym kierunku, używając do tego celu papieru toaletowego.

8. Spłukać muszlę! Jeśli skuteczność spłukania będzie za mała, nie popychać ręką - służy do tego szczotka!

9. Nie trzaskać klapą! Toaleta to nie fortepian.

10. Przy korzystaniu z pisuaru należy podejść do niego jak najbliżej, nawet dotykając go lekko kolanami, wyjąć całkowicie narząd moczowy, lekko nachylić go w dół i oddać mocz, aż do ostatniej kropli.

11. Korzystanie z toalety zgodnie z instrukcją spowoduje, że podłoga w toalecie będzie sucha i czysta. Życzymy wielu pomyślnych wypróżnień. 
Podobieństwa werbalne obydwu instruktażowych tekstów będą zwodnicze, niepodobna bowiem przejść do porządku nad formułą „środek przekazu jest przekazem": zdecydowanie czym innym wychodkowa realność instrukcji z 1988 roku, czym innym wirtualność instrukcji o mniej więcej ćwierćwiecze późniejszej.

Należy jeszcze podjąć pytanie o związki obydwu nikiformowych wypowiedzi z praktyką panoptyczną:

Można rzec z pewną dozą przesady, że zawieszony na sznurku zeszyt z przywiązanym długopisem pełnił w PRL-owskich sklepach nieco podobną funkcję do tej, jaka przypadła pustej wieży strażniczej w opisywanym przez Foucaulta więzieniu Benthama. ${ }^{42}$

Jednak zapewne jedynie przyklejona do ściany wychodka instrukcja (wszak nie nosi śladu nabicia na gwóźdź), jeśli w ogóle pełniła jakąkolwiek funkcję panoptyczną, to ta pozostawała znacząco słabsza. Efektywność sklepowych i wychodkowych słów to dwa wyzwania zasadniczo empiryczne - odpowiednich badań jednak nie przeprowadzono i dlatego należy jedynie poprzestać na bardziej intuicyjnych niż wiarygodnych wrażeniach, że potencjalny nadzór klientów nad sklepowym personelem pozostawał może nawet znacząco skuteczniejszy ${ }^{43}$ niż nadzór anonimowego autora instrukcji nad wozakami.

Tak więc, niezależnie od znamiennego dla urzędniczej Polski Ludowej wysłowienia, wychodkowa instrukcja może stać się materią przynajmniej trojakiej lektury, tj. jako: nikiforma, tekst czytany poprzez medium klasycznej teorii retorycznej z jej wymową pokazową oraz jako problem ponowoczesnej atrybucji gatunkowej. Jako literaturoznawcze wyzwania można jeszcze dodać - przykładowo - poetykę ksiąg zwanych „lasem rzeczy” czy też głupotę w jej filozoficznym sproblematyzowaniu ${ }^{44}$ ? Art brut i sztuka surowa? Może napotoczna niepozbawiona jest $w$ tym względzie trafnych rozwiązań, identyfikując $w$ żartach i komunałach nierozgarniętych policjantów czy nadzorców". J. Dobrowolski Filozofia głupoty, s. 258. Na marginesie: o ile anonimowy autor instrukcji zapewne może być określony jako "nie- 
wet literatura faktu i autentyzm twórczości hipermimetycznej? Ostatecznie instrukcja pozostaje tekstem zarazem zarówno historycznym (za sprawą jej społeczno-politycznego kontekstu), jak i ponadczasowym (gdyż curiosa mogą stawać się przedmiotem nieprzemijającej fascynacji).

\section{Abstract}

\section{Krzysztof Obremski}

NICOLAUS COPERNICUS UNIVERSITY (TORUŃ)

Instruction Manual of a Milk Catchment Lavatory: Nikiform - Demonstrative Utterance

- Genre

Had it been found a few years earlier, and not in the mid-1980s, the instruction manual of a milk catchment's lavatory could have made it into Edward Redliński's anthology of ready-made texts, Nikiformy (1982). The manual's clunky language is emblematic of the bureaucracy of the Polish People's Republic. More importantly, it can be read in three ways: as a nikiform, as a text to be understood in terms of classical rhetorics with its rhetorical genealogy, and as a problem of postmodern genre attribution. The manual is a historical text (thanks to its social and political context, namely the first half of the 1980s), as well as a timeless one (curiosa can become objects of abiding fascination).

\section{Keywords}

nikiform, genealogy, sanitary culture

rozgarnięty nadzorca", to już z policjantem rzecz trudniejsza, ponieważ w dekadach PRL uosobieniem komicznego nierozgarnięcia pozostawali milicjanci - znamienne, że w III RP dowcipy o stróżach prawa wymarły śmiercią naturalną - za sprawą transformacji ustrojowej. 